Article

\title{
The Impact of Corporate Social Responsibility on the Workforce of Selected Business Firms in the United Arab Emirates: A Nascent Economy
}

\author{
Jacob Cherian ${ }^{1, *}$ (1) and Robert Pech ${ }^{2}$ \\ 1 College of Business, Abu Dhabi University, P.O Box 59911 Abu Dhabi, United Arab Emirates \\ 2 Department of Social Sciences, Khalifa University of Science and Technology, P.O Box 127788, Abu Dhabi, \\ United Arab Emirates; robert.pech@kustar.ac.ae \\ * Correspondence: jacob.cherian@adu.ac.ae
}

Received: 15 October 2017; Accepted: 7 November 2017; Published: 12 November 2017

\begin{abstract}
The main purpose of this study is to explore the impact of Corporate Social Responsibility (CSR) on employees working in two United Arab Emirates (UAE)-based companies. "Hilti Emirates" and "EROS Group" are the two companies that engage in a number of CSR applications which were focused on India in 2015. The impact of CSR on the companies is the key focus in this study by gauging employees' and managers' perceptions. Primary data were collected by means of a prepared questionnaire that concentrated on employee and managerial behavior and attitudes, while secondary data were collected from theoretical articles and published company reports. Data were analyzed by means of statistical analysis using SPSS software. Methods like factor analysis, descriptive analysis and ANOVA in SPSS software are helpful in assessing the effect of CSR on employees, and hence companies, in the UAE. The main findings of the study are that employees can develop a behavioral change depending on the nature of CSR practices within the company. In turn, CSR polices are sustainable in relation to company profit which may vary from one company to another and one financial year to another. Therefore, this study concludes that employee behavior regarding CSR policies has notable and positive implications, relevant to the company as well as to the employees and management. The two leading UAE companies demonstrate a confluent pattern of CSR practices and effects that may also relate to employee behavior in other economies, although the researchers encourage more investigations to corroborate that view.
\end{abstract}

Keywords: corporate social responsibility; UAE; employees' behavior; shared value; policies

\section{Introduction}

The corporate sector influences a wide variety of fields such as government, education, health, the environment and work cultures across the world. They can assist in identifying, promoting and implementing successful policies and practices throughout society. The UAE is a nascent economy with its contemporary roots going back only to the discovery of fossil fuels in the late 1960s. As per the European Commission and the United Nations, Corporate Social Responsibility (CSR) guidelines should positively influence the triple bottom line, namely profits, protection of the environment and the fight for social justice. So, sustainable development within the UAE should imply that, with increasing wealth generation during the last half century, the interests of the public good as well as the environment should be stimulated. Flynn noted that among others, CSR was intended to support issues related to the welfare of children, women and environmental sustainability [1]. But awareness of CSR is not universal and there exist different perceptions of its policies and practices. The UAE has mainly advanced CSR policies to increase awareness within the business sector to support growing their businesses, as well as encouraging them to observe their responsibilities to support 
relationship-building with the community. This includes potential export markets in developing countries. This was one of the reasons the researchers selected Hilti Emirates and the EROS Group because these companies' CSR efforts were focused on India.

The UAE is a center of Middle Eastern and global growth which takes seriously the sustainability and responsible use of natural resources. This is applicable for both the rapid growth of government and the private sector, and the implementation of CSR has needed to be revised and updated to enhance its effectiveness to keep pace with growth. In the UAE, CSR is consistent with Islamic teachings. One aspect is for Muslims to consider community needs which entails anonymously distributing a portion of income called "Zakat" to the needy through charity distribution according to Qasim et al. [2]. UAE collectivism is high and is based on old traditions which view community welfare and family ties in a philanthropic manner. Even though CSR may be viewed as a form of philanthropy, at times it is considered by many Muslims as an obligatory religious undertaking, Al-Ali [3]. It is nowadays also integrated into the center of business activity, referred to as "shared value" as promulgated by Porter and Kramer [4]. CSR in the former version is a sustainable process which combines concern for those in need with their business goals as a means of providing for the community's public good. In the latter form, Porter and Kramer point out that shared value may assist both parties, with the company benefiting because by determining the most appropriate approaches it can generate competitive advantage [4]. Porter and Kramer observed that re-developing products and markets, the value chain and local cluster industries can have reciprocal benefits for companies and their communities. Porter and Kramer looked mainly outward; this study is more focused inwardly by appraising employees' perceptions of CSR. Kramer and Pfitzer [5], however, point to the difficulties of companies attempting to modify their environments because they note that turning competition into "coopetition" through the coordination of mutually reinforcing activities between companies presents challenges. For each of the two businesses under consideration in this investigation, CSR begins with a company assessment of the following aspects: environmental aspects, community engagement, employee well-being and attitudes. These aspects play a main role in the form of CSR as they implemented it.

The main aim of CSR is to embrace company responsibility so as to encourage a positive impact on productivity, the environment, employees, consumers, communities, stakeholders and other members of the public. Only a few studies so far have been published with emphasis on CSR's impact on employees, although there have been investigations about companies that only consider their business performance and stakeholder pressure but not the employee view-point. They mainly focused on interaction with stakeholders and CSR's impact on the bottom-line [6,7]. Where there is less productivity, turnover of the company will be affected, so it is also necessary to pay attention to employees' view-points and to their attitudes and behaviors related to each company's growth. Therefore, the goal of this investigation is to provide a quantitative insight into employees' perceptions.

In prefacing the research in "Hilti Emirates" and the "EROS Group" companies, the motivational factors which encouraged employees to contribute towards implementing the CSR policy of both companies were pivotal in driving the activities. These companies strongly set store by their employees' concern regarding their work-life balance and long term career growth. Specifically, the mission of the EROS Group (Dubai) is "To achieve and sustain competitive advantage in distribution and retailing by: Industry leading customer satisfaction, while constantly building loyalty and trust. Superior financial performance, while maintaining integrity and business ethics. Adding value to all stakeholders, while ensuring effective teamwork and mutual benefits" [8]. In 2017, the Eros Group was voted the UAE's choice superbrand for the seventh year in a row [8]. Hilti has similar aims, explaining that their Champion 2020 corporate strategy goals include achieving "sustainable value creation through leadership and differentiation. Market leadership through added value for our customers by offering products, services and software that provide superior productivity and safety to our customers and differentiate from the offering of our competitors." [9]. They also list one other noteworthy point in their strategy: "Our strategy stands on the strong foundation of our "caring and performance oriented" 
corporate culture [9]. This statement also explains why their employees have collected garbage in the desert area of $\mathrm{Al}$ Aweer [9]. Both companies have strategies in which strong human values play a part. Eros promotes "quality service, corporate loyalty and integrity, and trust and cooperation" [10]. Hilti speaks similarly of "partnership based cooperation [and] high performing global team" [9]. CSR then has been incorporated in both companies' strategies as a natural element of their culture and strategy.

As organizations, their managements asserted their belief that sustainable development of society and environment is necessary and they also gave credence to their employees' thoughts. These factors acted as incitement for their employees. The company secretaries, financial controllers and finance manager were the key members of the CSR committee of the companies. These key players framed the activities to be carried out and also encouraged the employees to actively participate. The encouragement proved pivotal to the success of the CSR strategies.

Bhattacharya and Sen believed that numerous business models are developed to incorporate CSR considerations such as diminishing the role of government, increasing demands for greater disclosure, increasing customer engagement, growing investor pressure, expanding competitive labor markets and enhancing supplier relations [11]. But in the UAE, there appear to be few links formally constructed between CSR and business strategy. Possibly due to the nascent nature of the economy, it is still in its infancy except in some leading companies. Therefore, the two companies that have been identified as such in this investigation follow a number of CSR policies and the aim is to measure the impact of CSR on their employees' behaviors and attitudes.

This research addresses a gap on the impact of CSR on employee behavior by focusing on Hilti Emirates and EROS Group. These two companies were chosen because they are both in rapidly expanding sectors: Hilti in construction and EROS in consumer electronics, both of which comprise important sectors in the UAE economy. They also both focus their CSR efforts on needs in India. Hilti in 2015 was a part of the construction industry which comprised 11.1 percent of the UAE economy. In a ten year time-span, the economy increased from 510.9 billion dirhams in 2006 to 1.8 trillion in 2016 [12]. Even though the UAE economy has demonstrated enviable growth, companies are often still nascent in their policies and practices which makes them ideal for an investigation into their evolution in CSR. It should be noted that, according to the Companies Act 2013, the budget allotted for CSR activities is $2 \%$ of the average net profit incurred by the companies in the last three financial years.

This research addresses a gap on the impact of CSR on employee behavior by focusing on Hilti Emirates and EROS Group as case-studies and assessing CSR impact empirically by addressing the following key questions.

1. How do employees respond to CSR policies implemented by their respective companies?

2. What aspects of CSR most influence and create an impact on employee behavior?

3. What conclusions can be drawn about the relationship between CSR and employee behavior?

\section{Literature Review}

The concept of CSR originated in the 1950s in Europe. The United Nations played a vital role in its dissemination and acceptance. CSR was initially promulgated under many names such as strategic philanthropy, corporate conscience, corporate citizenship, social performance, and sustainable responsible business. Also the implementation of CSR may vary according to country or region. Only in the late 1960s did the term "corporate social responsibility" enter into common use and awareness was increased by a book entitled Strategic Management: A Stakeholder Approach written by R. Edward Freeman in 1984.

According to Drucker ten years earlier in 1974, it was necessary that companies should involve themselves in social activities and in community welfare [13]. He pointed out that corporates earned profits from their community and were implicated in the depletion of natural resources, so he reasoned that they also should contribute to environmental sustainability and responsible utilization of natural 
resources. In 1970, Freeman opposed that concept and opined that corporations were not intended for social action, arguing instead that they were legal entities responsible in the first instance for producing quality products for consumers, on the basis of legal rules and regulations for contributing to a nation's economic development. This approach was relevant to both the Hilti and EROS companies under consideration in this investigation. The CSR activities of these companies are broadly classified into social consideration as well as demonstrating environmental consciousness. Their efforts at CSR focused abroad on the poor and below poverty groups living in Delhi, a large and much impoverished location in India. This company provided required food, education and also conducted various welfare programs for underprivileged people, the disabled, elderly people, women, and children specifically. The campaign conducted in Delhi for the poor was well received in 2015 by its Indian beneficiaries. But did employees of the two donor companies also benefit?

Employees involved themselves in the activities of their own interest and every one of them gave equal contribution. They were also involved in environmentally-based activities like:

- Green belt development

- Forestation, plantation of tree samplings

- Production of renewable source of projects

- Developing infrastructure for manufacturing solar lights

By 2001, theorists like Mohr et al. argued more in line with Drucker that CSR should be regarded as an essential commitment of a company to minimize or eliminate harmful influences and maximize long-term beneficial impacts on society [14]. According to Scott and Lane, previously in 2000, individuals tend to reinforce their self-image and esteem within groups and organizations [15]. They pointed out that organizational identity was closely aligned with stakeholder management. Cropanzano and Mitchell then promoted the view that social identity did not directly integrate with reciprocity, expectations and mutual obligations [16]. These were essential features in order to understand attitudes and behaviors of consumers and employees. While taking actions to alter dynamics between corporates and employees, in turn it would create a need for employees to move towards positive corporate social behavior, which formed one of the core elements in this investigation.

Ali et al. gave an overview on CSR-related studies: Many of the research outcomes concluded that the CSR concept should incorporate information for the consumer, and transparency regarding the community, competitors and the government [17]. These works were focused on advancements of the corporate world including diverse effects of CSR on corporate and CSR reporting methods. Other research works were related to CSR's significance and retention of different stakeholders and sustainable corporate performance. Then, in 2013, Delmas, Etzion and Nairn-Birch proposed that with data so readily accessible through the Internet, CSR decisions could be made more easily but that this could also increase the issues of "commensurability, information overload, and confusion" [18]. In attempting to assess corporate environmental performance, they focused on environmental processes and practices that companies applied and the environmental outcomes they created. They also concluded that corporate financial performance was linked to process but not to outcome measures [18]. In total, the significance of CSR appeared to be investigated in three main dimensions including a company's financial performance, consumer behavior and employee behavior. Kramer and Pfitzer proposed that markets and productivity are strongly related. They cite as just one example the Anglo American Company which mines in South Africa, and that instituted a treatment program for HIV / AIDS to minimize further employee infection as well as to reduce employee absenteeism [5].

CSR could directly influence employee behavior within corporations either in a positive way or the opposite. Swaen and Maignan identified a positive effect of CSR on employees' adoption of social responsive behavior within a corporation [19]. However, Valentine and Fleischman for the first time reported on the influence of CSR on job satisfaction, and mentioned that no studies had explored CSR's influence on employees' attitudes and behavior beyond organizational commitment [20]. Previously, it was believed that social identity was the major CSR influence on employee behavior. Aguilera et al. 
reported that CSR may influence employees through mechanisms other than social identification such as social exchange. They also explained that CSR may influence employee attitudes, needs and behavior besides commitment [21].

Rupp et al. pointed out that, in past literature regarding employees working under CSR policies, little had been investigated, although for the past two decades research in much greater quantity had focused on the relationship between leadership and CSR [22]. In 1991, Wood described CSR influence on employee attitude and behavior [23]. Later on there was no evident research carried out on this topic. To fill this research gap, our study was designed mainly to be based on employee attitudinal and behavioral change in relation to CSR practices, if indeed they were affected.

Vlachos et al. stated that employees were making three distinct observations about CSR and they identified them as follows: they called the social concern imbedded in an organization's action "procedural CSR", the outcomes of such actions, they called "distributive CSR"; and after the implementation of CSR they referred to "interactional CSR" as the way of treating interpersonal relations inside and outside the organization [24]. These determinations led to employee action that was placing some pressure on organizations to implement CSR initiatives. Some of the CSR initiatives in this category included organizational attraction, commitment, and retention; job satisfaction and performance; citizenship behaviors; and employee participation in leadership initiatives. Employee participation in CSR initiatives could also be direct by personal involvement, as well as indirect by moving socially responsible actions through performance and firm commitment.

\section{Research Methodology}

\subsection{Sample Size}

The sample organizations of Hilti Emirates and EROS group were selected as explained above but also because they were placed in the "Top 20 best organizations in 2015 in the UAE". Primary data were collected from employees working there. The researchers distributed the surveys to a population size of 100 per organization. With cooperation from each organization, employees were allowed to complete the survey during work hours. The research team assured all participants that their responses would be confidential and that there was no compulsion to participate. To select participants, the convenience sampling technique was followed for both genders. The members of a sample population belonged to different profession groupings, ages and genders. The survey was conducted in two stages: the first stage consisting of self-explanatory questions was given to participants; and in the second stage, questionnaires were collected from respondents after providing sufficient time for them to respond.

In this study, our proposed model attempts to make a three-fold contribution. Firstly, the researchers provide a new set of testable hypotheses to implement an empirical investigation of CSR's impact on employee behavior. Secondly, the model clarifies the relationship between the corporate sector's CSR practices and its impact on employee behavior that so far has been under-investigated. Finally, it evaluates CSR's impact within two leading UAE companies on employee behavior in a case-study approach. Such an approach has the advantages of focusing on detail and specifics. However, the researchers concede that the small scale is also this study's limitation and more investigations are needed to attempt to more adequately universalize the findings related to the impact of CSR on companies.

\subsection{Objectives}

\subsubsection{Primary Objective}

- To determine the impact of CSR on employee behavior in UAE-based companies. 


\subsubsection{Secondary Objectives}

- To study the theories and guidelines for CSR practices in UAE companies.

- To study the CSR practices as per GRI (Global Reporting Initiative) guidelines being implemented by UAE companies.

- To offer recommendations for better CSR practices from the employee viewpoint based on findings from this study.

\subsection{Hypothesis}

- H1: Employees provide a significant contribution towards the CSR activity of a company.

- H0: Employees do not provide a significant contribution towards the CSR activity of a company.

- H2: CSR activities of a company make a significant impact on employees.

- H0: CSR activities of a company do not make a significant impact on employees.

\subsection{Testing Methods Used}

First, the descriptive statistical analysis was completed. Based on the values of standard deviation obtained, the analysis test ANOVA was chosen which gave more accurate results than other methods. As per the literature review, the questionnaire was formed on the basis of CSR activities. The questions investigated the connection between theory, literature and practice in areas that are under-investigated to this point from a theoretical point of view, and especially from a practical point of view in an expanding but still-nascent economy such as the UAE's. The questionnaire was divided into "Employees" and "Management" to test perceptions on both sides of the productivity coin. The questions are largely in connections with value-sharing as per Porter and Kramer [4]; satisfaction, performance and citizenship behaviors as per Wood [23]; Cropanzano and Mitchell [16] as well as Vlachos et al. [24]; and whether employee attitude, needs and behaviors are distinct from work commitment following Aguilera et al. [21]. These issues are of interest because they relate to the core of organization/employee/society relationships. However, the extent of CSR's impact had not been previously determined.

\section{Findings}

This part discusses the impact of CSR carried out by an organization over its employees as well as employee contribution. The impact and contribution factors were analyzed using statistical methods.

A sample of 100 employees irrespective of their position was calculated from Hilti Emirates and EROS. A structured questionnaire was framed based on CSR activities followed by their company and the survey is conducted in it. Based upon the response from employees, the analysis was carried out. The topic questions are listed below.

In the analysis part, comparative mean analysis was used and one-way ANOVA (Analysis of Variance) method was used. Based upon the output value, the impact on employee as well as the employee's contribution towards CSR activities was determined.

\subsection{Reliability Analysis}

The variables considered for the reliability analysis are listed below:

Employees

- Do you think CSR activities carried out by your company suit its vision?

- Does your company have a proper board of directors to carry out CSR activities?

- Rate your contribution towards CSR activities.

- How good are you in time management when it comes to CSR combined with normal work?

- Have you ever thought that CSR activity was an obstacle? 
- Share your opinion on the importance of CSR activity towards an organization.

- Share your opinion on the importance of CSR activity towards an employee.

- Rate the impact of CSR activity on you.

- How would you contribute towards CSR activities?

- Share your satisfaction level towards CSR activities.

- Rate your employee contribution towards CSR activities.

Management

- Are you satisfied with your employees' contribution?

- Do you think that CSR activity carried out by your company suits the vision?

- Are you allocating a suitable budget?

- Do you have a board of directors to carry out CSR activities?

- What is the satisfaction level of your targeted people?

- Have you extended the number of CSR activities over the years?

- Please evaluate the success rate of your CSR activities?

- Based on what factors do you measure the success of CSR activities?

Before starting with the testing method, the reliability of the entire question set was tested using reliability analysis. Therefore, all 19 variables were taken into consideration and the reliability test was carried out using the Cronbach Alpha method, as specified in Table 1.

Table 1. Cronbach's Alpha and Number of Items Caption.

\begin{tabular}{cc}
\hline \multicolumn{2}{c}{ Reliability Statistics } \\
\hline Cronbach's Alpha & No of Items \\
0.781 & 19
\end{tabular}

The Cronbach Alpha method is used to test the reliability by analyzing its relevance to the concept. Hence, the reliability of the entire question set was analyzed and compared with the standard value. The calculated value was $(0.781 \geq 0.7)$. This is greater than or equal to the standard value and so the researchers considered that the output obtained was the best fit and had purposeful relevance to the concept.

\subsection{Hypothesis 1}

The first hypothesis discusses the contribution of employees towards CSR activities carried out by their organization. This involves an employee's contribution as an independent variable and the success rate of CSR is known as a dependent variable. Therefore, based on the contribution from the employee side, the success of a CSR activity of any company depends on the parameters like self-ratings by the employees, self-satisfaction and means of contribution and management's rating. These factors are considered as the independent variable. The employee contribution for the success rate and methods to measure it were considered as dependent variables.

Table 2 indicates that the largest standard deviation is not more than twice the smallest standard deviation. So, the data is allowing to use one way ANOVA. 
Table 2. Hypothesis 1 descriptive statistics.

\begin{tabular}{cccccc}
\hline & N & Minimum & Maximum & Mean & Std. Deviation \\
\hline Rate your contribution towards CSR activities. & 200 & 1.00 & 5.00 & 3.4600 & 1.25550 \\
\hline $\begin{array}{c}\text { How good are you in time management when } \\
\text { it comes to CSR and work? }\end{array}$ & 200 & 1.00 & 4.00 & 1.7350 & 0.95358 \\
\hline $\begin{array}{c}\text { How would you contribute towards the } \\
\text { CSR activities? }\end{array}$ & 200 & 1.00 & 4.00 & 1.8200 & 0.93379 \\
\hline $\begin{array}{c}\text { Share your satisfaction level towards } \\
\quad \text { CSR activities. }\end{array}$ & 200 & 1.00 & 5.00 & 3.4600 & 1.25550 \\
\hline $\begin{array}{c}\text { Rate your employee contribution towards } \\
\text { CSR activities. }\end{array}$ & 200 & 1.00 & 4.00 & 1.7350 & 0.95358 \\
\hline $\begin{array}{c}\text { What is the satisfaction level of your } \\
\text { targeted people? }\end{array}$ & 200 & 1.00 & 4.00 & 1.7350 & 0.95358 \\
\hline $\begin{array}{c}\text { Have you extended the number of CSR } \\
\text { activities over the years? }\end{array}$ & 200 & 1.00 & 2.00 & 1.1600 & .36753 \\
\hline $\begin{array}{c}\text { On what factors do you measure the success of } \\
\text { CSR activities? }\end{array}$ & 200 & 1.00 & 5.00 & 2.9400 & 1.32103 \\
\hline $\begin{array}{c}\text { Please rate the success of your CSR activities. } \\
\text { Valid N (list-wise) }\end{array}$ & 200 & 1.00 & 5.00 & 3.4600 & 1.25550 \\
\hline$\quad$ Largest standard deviation = 3.46; smallest standard deviation = 1.16.
\end{tabular}

In Table 3, the comparison of the factors involving the success of a CSR activity and its contribution had the significant value of 0.012 . Therefore, the conclusion is that the employee's contribution is not up to the mark. This is because not every employee contributes equally, so the researchers suggest that every employee of an organization should be encouraged to provide an equal contribution. The employee's time management in connection with their CSR activity and its impact on its success obtained an output of $0.540,0.775$. Therefore, the conclusion is that the employee who makes a contribution to a CSR activity finds time to manage that as well as his or her own designated work. The comparison of the success rate of the CSR activity with the contribution given by the employees showed a significant impact. The employees contribute through various means like volunteer work promoting their activity, educating the targeted beneficiaries, etc. The results of the analysis concludes that the methods approached by the employees are effective since the calculated value is greater than the standard value $(0.956>0.05),(0.437>0.05)$. The satisfaction level of every single employee in CSR activity is discussed. Based on the satisfaction level, their contribution towards CSR as well as the success rate can be calculated. As a result of this analysis, the output shows that the calculated value is less than the standard value $(0.012<0.05)$. Hence, the conclusion is that not all the employees are satisfied with CSR activities. This may have two main reasons behind it: either they were not assigned to their area of interest or they are not interested in CSR in the first place.

Table 3. Analysis of variance (ANOVA).

\begin{tabular}{|c|c|c|c|c|c|c|}
\hline Factors & & $\begin{array}{l}\text { Sum of } \\
\text { Squares }\end{array}$ & df & $\begin{array}{l}\text { Mean } \\
\text { Square }\end{array}$ & $\mathbf{F}$ & Sig \\
\hline \multirow{3}{*}{$\begin{array}{l}\text { By means of which factors do you measure the } \\
\text { success of CSR activities? } \\
\text { Rate your contribution towards CSR activities. }\end{array}$} & Between Groups (Combined) & 22.086 & 4 & 5.521 & 3.311 & 0.012 \\
\hline & Within Groups & 325.194 & 195 & 1.669 & & \\
\hline & Total & 347.280 & 199 & & & \\
\hline \multirow{3}{*}{$\begin{array}{l}\text { Based on what factors do you measure the } \\
\text { success of CSR activities? } \\
\text { How good are you in time management when it } \\
\text { comes to CSR and work? }\end{array}$} & Between Groups (Combined) & 3.791 & 3 & 1.264 & 0.721 & 0.540 \\
\hline & Within Groups & 343.489 & 196 & 1.752 & & \\
\hline & Total & 347.280 & 199 & & & \\
\hline \multirow{3}{*}{$\begin{array}{l}\text { Consider the success rate of your CSR activities. } \\
\text { How good are you in time management when it } \\
\text { comes to CSR and work? }\end{array}$} & Between Groups (Combined) & 1.764 & 3 & 0.588 & 0.370 & 0.775 \\
\hline & Within Groups & 311.916 & 196 & 1.591 & & \\
\hline & Total & 313.680 & 199 & & & \\
\hline
\end{tabular}


Table 3. Cont.

\begin{tabular}{|c|c|c|c|c|c|c|}
\hline Factors & & $\begin{array}{l}\text { Sum of } \\
\text { Squares }\end{array}$ & df & $\begin{array}{l}\text { Mean } \\
\text { Square }\end{array}$ & $\mathbf{F}$ & Sig \\
\hline \multirow{3}{*}{$\begin{array}{l}\text { Based on what factors do you measure the } \\
\text { success of CSR activities? } \\
\text { How would you contribute towards the } \\
\text { CSR activities? }\end{array}$} & Between Groups (Combined) & 0.564 & 3 & 0.188 & 0.106 & 0.956 \\
\hline & Within Groups & 346.716 & 196 & 1.769 & & \\
\hline & Total & 347.280 & 199 & & & \\
\hline \multirow{3}{*}{$\begin{array}{l}\text { Consider the success rate of your CSR activities. } \\
\text { How would you contribute towards the } \\
\text { CSR activities? }\end{array}$} & Between Groups (Combined) & 4.309 & 3 & 1.436 & 0.910 & 0.437 \\
\hline & Within Groups & 309.371 & 196 & 1.578 & & \\
\hline & Total & 313.680 & 199 & & & \\
\hline \multirow{3}{*}{$\begin{array}{c}\text { Based on what factors do you measure the } \\
\text { success of CSR activities? } \\
\text { Share your satisfaction level towards } \\
\text { CSR activities. }\end{array}$} & Between Groups (Combined) & 22.086 & 4 & 5.521 & 3.311 & 0.012 \\
\hline & Within Groups & 325.194 & 195 & 1.668 & & \\
\hline & Total & 347.280 & 199 & & & \\
\hline \multirow{3}{*}{$\begin{array}{l}\text { Based on what factors do you measure the } \\
\text { success of CSR activities? } \\
\text { Rate your employee contribution towards } \\
\text { CSR activities. }\end{array}$} & Between Groups (Combined) & 3.791 & 3 & 1.264 & 0.721 & 0.540 \\
\hline & Within Groups & 343.489 & 196 & 1.752 & & \\
\hline & Total & 347.280 & 199 & & & \\
\hline \multirow{3}{*}{$\begin{array}{c}\text { Consider the success rate of your CSR activities. } \\
\text { Rate your employee contribution towards } \\
\text { CSR activities. }\end{array}$} & Between Groups (Combined) & 1.764 & 3 & 0.588 & 0.370 & 0.775 \\
\hline & Within Groups & 311.916 & 196 & 1.591 & & \\
\hline & Total & 313.680 & 199 & & & \\
\hline \multirow{3}{*}{$\begin{array}{c}\text { Based on what factors do you measure the } \\
\text { success of CSR activities? } \\
\text { What is the satisfaction level of your } \\
\text { targeted people? }\end{array}$} & Between Groups (Combined) & 3.791 & 3 & 1.264 & 0.721 & 0.540 \\
\hline & Within Groups & 343.489 & 196 & 1.752 & & \\
\hline & Total & 347.280 & 199 & & & \\
\hline \multirow{3}{*}{$\begin{array}{c}\text { Consider the success rate of your CSR activities. } \\
\text { What is the satisfaction level of your } \\
\text { targeted people? }\end{array}$} & Between Groups (Combined) & 1.764 & 3 & 0.588 & 0.370 & 0.775 \\
\hline & Within Groups & 311.916 & 196 & 1.591 & & \\
\hline & Total & 313.680 & 199 & & & \\
\hline \multirow{3}{*}{$\begin{array}{c}\text { Based on what factors do you measure the } \\
\text { success of CSR activities? } \\
\text { Did you extended the number of CSR activities } \\
\text { over the years? }\end{array}$} & Between Groups (Combined) & 0.137 & 1 & 0.137 & 0.078 & 0.780 \\
\hline & Within Groups & 347.143 & 198 & 1.753 & & \\
\hline & Total & 347.280 & 199 & & & \\
\hline \multirow{3}{*}{$\begin{array}{c}\text { Consider the success rate of your CRS activities. } \\
\text { Did you extend the number of CSR activities } \\
\text { over the years? }\end{array}$} & Between Groups (Combined) & 0.275 & 1 & 0.275 & 0.174 & 0.677 \\
\hline & Within Groups & 313.045 & 198 & 1.583 & & \\
\hline & Total & 313.680 & 199 & & & \\
\hline
\end{tabular}

The employee contribution was also analyzed from the management point of view. Since the calculated value is higher than the standard value $(0.540>0.05)$, the conclusion is that management are satisfied with their employee's contribution. Based upon the satisfaction of targeted people, the CSR activity of a company is considered to be successful. The results conclude that the targeted people were satisfied with the CSR activity carried out by the company because they got benefit from it. Employees of the organization play an important role here: without their contribution, targeted people will not get the benefit and the organization would not be successful in its aims. The calculated value is also supportive where significant value is higher than the standard value $(0.540>0.05)(0.775>0.05)$. The expansion of the number of CSR activities carried out by the company were analyzed. This is only possible if their initial activity was successful and an employee's contribution was important in both aspects and therefore the overall CSR success rate was high. Analysis also shows that the calculated values are higher than the standard value $(0.780>0.05)(0.677>0.05)$. Therefore, the conclusion is that both the companies carry out more than one CSR activity and are also successful in this. Employees of these organizations contributed significantly.

\subsection{Hypothesis 2}

This hypothesis discusses the impact created by CSR activities carried out by the organization towards the employees. It also further discusses what kind of impact these activities have on employees and how they respond towards it. The employees are from the two companies selected from the UAE. 
In Table 4, it is clear that the largest standard deviation is not more than twice the smallest standard deviation. So, the data is enabling the researchers to use one way ANOVA. Table 5 below indicates this.

Table 4. Hypothesis 2 descriptive statistics.

\begin{tabular}{|c|c|c|c|c|c|}
\hline & $\mathbf{N}$ & Minimum & Maximum & Mean & Std. Deviation \\
\hline $\begin{array}{c}\text { Do you think CSR activities carried out by your company } \\
\text { suits its vision? }\end{array}$ & 200 & 1.00 & 2.00 & 1.3650 & 0.48264 \\
\hline $\begin{array}{c}\text { Does your company have a properly constituted board of } \\
\text { directors to carry out CSR activities? }\end{array}$ & 200 & 1.00 & 2.00 & 1.1600 & 0.36753 \\
\hline Have you ever thought that CSR activities were an obstacle? & 200 & 1.00 & 2.00 & 1.3650 & 0.48264 \\
\hline $\begin{array}{l}\text { Share your opinion on the importance of CSR activity towards } \\
\text { an organization. }\end{array}$ & 200 & 1.00 & 5.00 & 3.4600 & 1.25550 \\
\hline Rate the impact of CSR activity on you. & 200 & 1.00 & 5.00 & 2.9400 & 1.32103 \\
\hline Do you allocate a budget? & 200 & 1.00 & 2.00 & 1.1600 & 0.36753 \\
\hline On what factors do you measure the success of CSR activities? & 200 & 1.00 & 5.00 & 2.9400 & 1.32103 \\
\hline Please rate the success of your CSR activities. & 200 & 1.00 & 5.00 & 3.4600 & 1.25550 \\
\hline Valid N (list-wise) & 200 & & & & \\
\hline
\end{tabular}

Largest standard deviation $=3.46$; smallest standard deviation $=1.16$.

Table 5. Analysis of variance (ANOVA).

\begin{tabular}{|c|c|c|c|c|c|c|}
\hline \multicolumn{2}{|l|}{ Factors } & \multirow{2}{*}{$\begin{array}{c}\begin{array}{c}\text { Sum of } \\
\text { Squares }\end{array} \\
7.288\end{array}$} & \multirow{2}{*}{$\begin{array}{c}\text { df } \\
1\end{array}$} & \multirow{2}{*}{$\begin{array}{c}\text { Mean } \\
\text { Square } \\
7.288\end{array}$} & \multirow{2}{*}{$\begin{array}{c}\mathbf{F} \\
4.244\end{array}$} & \multirow{2}{*}{$\begin{array}{l}\text { Sig } \\
0.041\end{array}$} \\
\hline $\begin{array}{l}\text { Based on what factors do you measure the } \\
\text { success of CSR activities? }\end{array}$ & $\begin{array}{l}\text { Between Groups } \\
\text { (Combined) }\end{array}$ & & & & & \\
\hline \multirow{2}{*}{$\begin{array}{l}\text { Do you think CSR activities carried out by your } \\
\text { company suit its vision? }\end{array}$} & Within Groups & 339.992 & 198 & 1.717 & & \\
\hline & Total & 347.280 & 199 & & & \\
\hline \multirow{3}{*}{$\begin{array}{l}\text { Consider the success rate of your CSR activities. } \\
\text { Do you think CSR activities carried out by your } \\
\text { company suit its vision? }\end{array}$} & $\begin{array}{l}\text { Between Groups } \\
\text { (Combined) }\end{array}$ & 8.995 & 1 & 8.995 & 5.846 & 0.017 \\
\hline & Within Groups & 304.685 & 198 & 1.539 & & \\
\hline & Total & 313.680 & 199 & & & \\
\hline \multirow{3}{*}{$\begin{array}{l}\text { Based on what factors do you measure the } \\
\text { success of CSR activities? } \\
\text { Does your company have a board or any } \\
\text { directors to carry out CSR activities? }\end{array}$} & $\begin{array}{l}\text { Between Groups } \\
\text { (Combined) }\end{array}$ & 0.137 & 1 & 0.137 & 0.078 & 0.780 \\
\hline & Within Groups & 347.143 & 198 & 1.753 & & \\
\hline & Total & 347.280 & 199 & & & \\
\hline \multirow{3}{*}{$\begin{array}{c}\text { Consider the success rate of your CSR activities. } \\
\text { Does your company have a board or any } \\
\text { directors to carry out CSR activities? }\end{array}$} & $\begin{array}{l}\text { Between Groups } \\
\text { (Combined) }\end{array}$ & 0.275 & 1 & 0.275 & 0.174 & 0.677 \\
\hline & Within Groups & 313.405 & 198 & 1.583 & & \\
\hline & Total & 313.680 & 199 & & & \\
\hline \multirow{3}{*}{$\begin{array}{l}\text { Based on what factors do you measure the } \\
\text { success of CSR activities? } \\
\text { Have you ever thought that CSR activities were } \\
\text { an obstacle in the company? }\end{array}$} & $\begin{array}{l}\text { Between Groups } \\
\text { (Combined) }\end{array}$ & 7.288 & 1 & 7.288 & 4.244 & 0.041 \\
\hline & Within Groups & 339.992 & 198 & 1.717 & & \\
\hline & Total & 347.280 & 199 & & & \\
\hline \multirow{3}{*}{$\begin{array}{c}\text { Consider the success rate of your CSR activities. } \\
\text { Have you ever thought of a CSR activity as an } \\
\text { obstacle in company? }\end{array}$} & $\begin{array}{l}\text { Between Groups } \\
\text { (Combined) }\end{array}$ & 8.995 & 1 & 8.995 & 5.846 & 0.017 \\
\hline & Within Groups & 304.685 & 198 & 1.539 & & \\
\hline & Total & 313.680 & 199 & & & \\
\hline \multirow{3}{*}{$\begin{array}{l}\text { Based on what factors do you measure the } \\
\text { success of CSR activities? } \\
\text { Share your opinion on the importance of CSR } \\
\text { activity towards an organization and workers. }\end{array}$} & $\begin{array}{l}\text { Between Groups } \\
\text { (Combined) }\end{array}$ & 22.086 & 4 & 5.521 & 3.311 & 0.012 \\
\hline & Within Groups & 325.194 & 195 & 1.668 & & \\
\hline & Total & 347.280 & 199 & & & \\
\hline
\end{tabular}


Table 5. Cont.

\begin{tabular}{|c|c|c|c|c|c|c|}
\hline Factors & & $\begin{array}{l}\text { Sum of } \\
\text { Squares }\end{array}$ & df & $\begin{array}{l}\text { Mean } \\
\text { Square }\end{array}$ & $\mathbf{F}$ & Sig \\
\hline \multirow{3}{*}{$\begin{array}{c}\text { Consider the success rate of your CSR activities? } \\
\text { Rate the impact of CSR activity on you } \\
\text { organization and workers. }\end{array}$} & $\begin{array}{l}\text { Between Groups } \\
\text { (Combined) }\end{array}$ & 6.440 & 4 & 1.610 & 1.022 & 0.397 \\
\hline & Within Groups & 307.240 & 195 & 1.576 & & \\
\hline & Total & 313.680 & 199 & & & \\
\hline \multirow{3}{*}{$\begin{array}{c}\text { Based on what factors do you measure the } \\
\text { success of CSR activities? } \\
\text { Do you allocate a specific budget? }\end{array}$} & $\begin{array}{l}\text { Between Groups } \\
\text { (Combined })\end{array}$ & 0.137 & 1 & 0.137 & 0.078 & 0.780 \\
\hline & Within Groups & 347.143 & 198 & 1.753 & & \\
\hline & Total & 347.280 & 199 & & & \\
\hline \multirow{3}{*}{$\begin{array}{l}\text { Consider the success rate of your CSR activities. } \\
\text { Do you allocate a specific budget? }\end{array}$} & $\begin{array}{l}\text { Between Groups } \\
\text { (Combined })\end{array}$ & 0.275 & 1 & 0.275 & 0.174 & 0.677 \\
\hline & Within Groups & 313.405 & 198 & 1.583 & & \\
\hline & Total & 313.680 & 199 & & & \\
\hline
\end{tabular}

The authors note that a board is necessary because it is necessary for an organization to have a separate group of directors to guide the company in carrying out CSR activities, mainly to provide strategy and the authority to implement it. Therefore, from the analysis $(0.780>0.05)(0.677>0.05)$, the conclusion is that the companies do have proper boards or a group of directors for guidance. CSR activity as an obstacle to the organization and workers is considered to be one of the important factors providing impact of CSR over the employees. The employees were surveyed on the importance of CSR and most of them replied that it is an obstacle since they have to spend extra time, and only few among them are involved. The survey analysis also supports the theory where calculated value is less than the standard value (0.041) (0.017). Employees feel that the CSR activities are not important for an organization $(0.05>0.012)$. The individual feeling of the employees are shared and all their views are taken into account. The overall impact of CSR activity on the employee is discussed. According to the analysis, the conclusion is that the CSR activity creates a significant impact on them and makes them get involved and makes a useful contribution towards the organization helping to achieve success. The calculated value is higher than the standard value $(0.397>0.05)$. Hence, the CSR activity creates a positive impact on employees. The budget allocated by the organization for CSR activities is focused and this question was targeted at Management. A budget has to be allocated to carry out the CSR activity successfully. The survey concludes $(0.780>0.05)(0.677>0.05)$ that the companies allocate enough funding to carry out their CSR activities. Therefore, employees can manage and distribute the amount accordingly.

\section{Discussion}

The results from the overall analysis showed that a proportion of employees at the initial stage had a feeling that a CSR activity was not important and considered it as an impediment to their own work. CSR embraces the responsibility of the company to encourage a positive impact on work, the environment, employees, consumers, communities, stakeholders and other members of the public. After the motivation program devised by Management, they recognized the significance of CSR and were more willing to contribute to their organization. Management considered employees as the "backbone", as Kramer and Pfitzer proposed [5]. They carry out the CSR work and the organization depended on them for its success. Active participation of employees is also necessary for a CSR activity to be successful and the success is based on the satisfaction of targeted beneficiaries. Hence, it may be considered as a chain process of mutual dependencies.

However, the "shared value" between companies as promulgated by Porter and Kramer in 2011 was not evident. Whilst not explicitly tested for, there was no indicative evidence of any kind that employees or their management teams considered that shared value was desirable or necessary, or 
indeed that they had even considered such industrial relationships. This makes for a good subject to be investigated further in the future.

\section{Conclusions}

Therefore, from the above study, the conclusion is that the CSR activities of the two organizations in the study created a significant impact on their employees under circumstances in which "communication [and] mutually reinforcing activities" were encouraged as per Kramer and Pfitzer [5]. In turn, the employees made a significant contribution towards the success of CSR activities and therefore to the satisfaction of targeted people. This demonstrates a strong alignment mainly with literature from the early 2000s onwards: Mohr et al. [14]; Cropanzano and Mitchell [16]; Aguilera et al. [21]; Delmas et al. [18]. In large measure, there is a demonstrable connection between CSR and positive company perceptions in the majority of respondents. Even though the UAE is a nascent economy rather than a mature one, employees demonstrated positive corporate social behavior. In turn, this assisted the success of the company through the companies' cultures of cooperation and a belief that philanthropy is beneficial to those whose situation merits it and receives it. This is significant because it means that Management can create a culture of CSR collaboration out of employees from diverse backgrounds whose national cultures and ideologies obviously differ from one another. However, it also has to be noted that in an economy which comprises a heterogeneous workforce of many nationalities, there is also considerable variation of opinion. At last count, Dubai's workforce comprised almost 200 nationalities: the Emirati population is the indigenous one, and all others are expatriates [12].

While there appears to be consensus towards the positive impact of CSR, there is clearly no unanimity, nor would it be reasonable to expect that. Nonetheless, in an economically competitive world, even a consensus of positivity within diverse employees within a company enhances their work situation and to some extent improves the life experience of beneficiaries, in this case in Delhi. Likewise, it is reasonable to anticipate then that recipients of CSR in most contexts would benefit, and that this is not limited only to those in developing countries, but also within the communities where companies are actually located.

\section{Recommendations}

1. Management may successfully introduce CSR programs into their mission, strategy and operations in conjunction with boards that provide guidance and authorization, and employees who comprise the implementation force.

2. Management must determine the "benefit" proposition for its CSR program to provide to the maximum. This can go beyond philanthropy into the wider industrial realm where formerly-competing companies, stakeholders and their communities at large can create a mutually reciprocating ecosystem through the "shared value" proposition.

3. Management must incorporate communications and adequate funding to instill an appreciation of the potential benefits of CSR and any expertise required for implementation, so that a CSR program of any kind has a satisfactory chance of succeeding.

4. Metrics such as those in this investigation should measure the success of a CSR program according to the perceptions of both the company as well as the recipients.

5. CSR programs should be placed on a performance loop with changes and modifications where required to obtain the best possible outcomes for the company and its beneficiaries.

6. CSR programs may be located locally, nationally or internationally so that companies look beyond their own value chain and in so doing they expand their "interactional CSR" with a broader base of stakeholders.

7. It is advisable that a company constantly revises and updates its CSR policies to enhance growth and their brand reputation, as well as to contribute to the public good. 
Author Contributions: Jacob Cherian conceived and designed the experiments; Jacob Cherian performed the experiments; Jacob Cherian and Robert Pech analyzed the data; Robert Pech contributed analysis tools; Jacob Cherian and Robert Pech wrote the paper; Robert Pech completed the literature review, wrote the conclusion and the recommendations, and edited the paper overall.

Conflicts of Interest: The authors declare no conflict of interest.

\section{References}

1. Flynn, F.J. Identity orientations and forms of social exchange in organizations. Acad. Manag. Rev. 2005, 30, 737-750. [CrossRef]

2. Qasim, Z.; Muralidharan, P.; Ramaswamy, G. Corporate Social Responsibility and Impact of CSR practices in the United Arab Emirates. In Proceedings of the International Conference on Technology and Business Management, Shaheed Zulfikar Ali Bhutto Institute of Science and Technology, Dubai, United Arab Emirates, 28-30 March 2016.

3. Al-Ali, J. Emiratisation: Drawing UAE nationals into their surging economy. Int. J. Sociol. Soc. Policy 2007, 28, 365-379. [CrossRef]

4. Porter, M.C.; Kramer, M.R. Creating Shared Value. 2011. Available online: https://ncg.org/sites/default/ files/resources/HarvardBusinessReview_Creating_Shared_Value.pdf (accessed on 29 October 2017).

5. Kramer, M.R.; Pfitzer, M.W. The econsystem of shared value. Harv. Bus. Rev. 2016, 94, 80-89.

6. Aupperle, K.E.; Carrol, A.B.; Hatfield, J.D. An empirical examination of the relationship between corporate social responsibility and profitability. Acad. Manag. Rev. 1985, 28, 446-463. [CrossRef]

7. Carroll, A.B. Corporate social responsibility-Evolution of a definitional construct. Bus. Soc. 1999, 38, 268-295. [CrossRef]

8. EROS Group. Available online: https://www.erosgroup.ae/press/ (accessed on 28 October 2017).

9. Hilti. Available online: https://www.hilti.ae/content/hilti/META/AE/en/company/corporateinformation/CORPORATESTRATEGY.html (accessed on 28 October 2017).

10. EROS Group. Available online: https://www.erosgroup.ae/about-us/corporate-culture.aspx (accessed on 27 October 2017).

11. Bhattacharya, C.B.; Sen, S. Doing better at doing good: When, why, and how consumers respond to corporate social initiatives. Calif. Manag. Rev. 2004, 47, 9-24. [CrossRef]

12. Annual Economic Report 2016. Ministry of Economy, United Arab Emirates. Available online: http:/ / www.economy.gov.ae/Publications/MOE\%20Anual\%20Repoert\%20English\%202016.pdf (accessed on 29 October 2017).

13. Drucker, P.F. Management: Tasks, Responsibilities, Practices; Harper \& Row: New York, NY, USA, 1974.

14. Mohr, L.A.; Webb, D.J.; Harris, K.E. Do consumers expect companies to be socially responsible? The impact of corporate social responsibility on buying behaviour. J. Consum. Aff. 2001, 35, 45-72. [CrossRef]

15. Scott, S.G.; Lane, V.R. A stakeholder approach to organizational identity. Acad. Manag. Rev. 2000, 25, 43-62.

16. Cropanzano, R.; Mitchell, M.S. Social exchange theory: An interdisciplinary review. J. Manag. 2005, 31, 874-900. [CrossRef]

17. Ali, I.; Rehman, K.U.; Yilmaz, A.K.; Nazir, S.; Ali, J.F. Effects of corporate social responsibility on consumer retention in cellular industry of Pakistan. Afr. J. Bus. Manag. 2010, 4, 475-485.

18. Delmas, M.; Etzion, D.; Nairn-Birch, N. Triangulating environmental performance: What do corporate social responsibility ratings really capture? Acad. Manag. Perspect. 2013, 27, 255-266. [CrossRef]

19. Swaen, V.; Maignan, I. Organizational Citizenship and Corporate Citizenship: Two Constructs, One Research Theme? In Business Rites, Writs and Responsibilities: Readings on Ethics and Social Impact Management; True, S.L., Pelton, L., Eds.; Kennesaw State University: Kennesaw, GA, USA, 2003; pp. 105-130.

20. Valentine, S.; Fleischman, G. Ethics programs, perceived corporate social responsibility and job satisfaction. J. Bus. Ethics 2008, 77, 159-172. [CrossRef]

21. Aguilera, R.; Rupp, D.E.; Williams, C.A.; Ganapathi, J. Putting the s back in corporate social responsibility: A multilevel theory of social change in organizations. Acad. Manag. Rev. 2007, 32, 836-863. [CrossRef]

22. Rupp, D.E.; Gananpathy, J.; Aguilera, R.V.; Williams, C.A. Employees' reactions to corporate social responsibility: An organizational justice framework. J. Organ. Behav. 2006, 27, 537-543. [CrossRef] 
23. Wood, D.J. Corporate social performance revisited. Acad. Manag. Rev. 1991, 16, 691-718.

24. Vlachos, P.A.; Panagopoulos, N.G.; Rapp, A.A. Employee judgments of and behaviors toward corporate social responsibility: A multi-study investigation of direct, cascading, and moderating effects. J. Organ. Behav. 2014, 35, 990-1017. [CrossRef] 